Institute of $\mathbf{F}_{\text {ood and }} \mathbf{A}_{\text {gricultural }} \mathbf{S}_{\text {ciences }}$

\title{
Florida Solid and Hazardous Waste Regulation Handbook: Underground Storage Tanks (UST) ${ }^{1}$
}

\section{Michael T. Olexa, Aaron Leviten, and Kelly Samek ${ }^{2}$}

An underground storage tank is any storage tank that has more than 10 percent of its volume below the surface of the ground. This 10 percent includes piping. USTs are very special and DEP has paid close attention to them, giving them their very own series of regulations. Title 62-761 was passed in 1990 and refers solely to USTs. This regulation also provides that certain types of tanks would be exempt from these regulations.

\section{What Kinds of USTs Are Exempt from Regulation?}

The exemptions include, among others:

- any storage tank system with an individual capacity of 110 gallons or less.

- any agricultural storage tank system with a capacity of 550 gallons or less.

- any storage tank system used for storing heating oil for consumptive use on the premises where stored.

- any septic tank.

- any surface impoundment, pit, pond, or lagoon.

- any stormwater or wastewater collection system.

- any residential storage tank system.

Because most farmers and ranchers will meet one or more of these exemptions, their USTs usually will not be subject to regulation under this particular rule. However, any discharges or leaks will still be regulated under the federal RCRA, the state's RRMA, and any other statute that may apply. If you do not fall within these exemptions, we recommend that you contact the regional DEP office in your area for more information on the regulation of USTs.

\section{Acknowledgments}

The authors are indebted to the personnel of both state and federal agencies who gave their time and advice in the preparation of this handbook. The authors are also indebted to the following University of Florida personnel for a review and critique of the

1. This is EDIS document FE459, a publication of the Department of Food and Resource Economics, Florida Cooperative Extension Service, UF/IFAS, University of Florida, Gainesville, FL. Published December 2003. Please visit the EDIS website at http://edis.ifas.ufl.edu.

2. Michael T. Olexa, Professor in the Department of Food and Resource Economics and Director of the Agricultural Law Center, Florida Cooperative Extension Service, UF/IFAS, University of Florida, Gainesville, FL, and Member of the Florida Bar and Chair of the Agricultural Law Committee of the Florida Bar; Aaron Leviten, Attorney in Orlando and guest lecturer on pesticide litigation at the University of Florida; and Kelly Samek, 2003 graduate of the Levin College of Law at the University of Florida.

The Institute of Food and Agricultural Sciences is an equal opportunity/affirmative action employer authorized to provide research, educational information and other services only to individuals and institutions that function without regard to race, color, sex, age, handicap, or national origin. For information on obtaining other extension publications, contact your county Cooperative Extension Service office. Florida Cooperative Extension Service/Institute of Food and Agricultural Sciences/University of Florida/Christine Taylor Waddill, Dean. 
first draft of this publication: Dr. Thomas Dean, Pesticide Education Specialist, and Dr. Norman Nesheim, Pesticide Information Coordinator. Special recognition is also due to Mr. Richard Budell of the Office of Agricultural Water Policy of the Florida Department of Agriculture and Consumer Services for providing funds for the development of this handbook.

This handbook is designed to provide an accurate, current, and authoritative summary of the principal Florida laws that directly or indirectly relate to agriculture. It should provide a basic overview of the many rights and responsibilities farmers and farmland owners have under Florida laws. The reader is provided information about these rights and responsibilities and the appropriate contacts for more detailed information. However, the reader should be aware that because the laws, administrative rulings, and court decisions on which this publication is based are subject to constant revision, portions of this publication could become outdated at any time. Many details of cited laws are also left out due to space limitations.

This handbook is distributed with the understanding that the authors are not engaged in rendering legal or other professional advice and the information contained herein should not be regarded or relied upon as a substitute for professional advice. It is not all-inclusive in providing information to achieve compliance with laws and regulations governing the practice of agriculture. For these reasons, the use of these materials by any person constitutes an agreement to hold harmless the authors, UF/IFAS, the Agricultural Law Center, and the University of Florida for any liability claims, damages, or expenses that may be incurred by any person as a result of reference to or reliance upon the information contained in this publication. 